\title{
Dispersion and aggregation patterns of tree species in Araucaria Forest, Southern Brazil
}

\author{
JOÃO PAULO DE MAÇANEIRO ${ }^{1}$, ANDRÉ LUÍS DE GASPER ${ }^{2}$, \\ FRANKLIN GALVÃO ${ }^{3}$ and LAURI A. SCHORN ${ }^{4}$
}

\begin{abstract}
${ }^{1}$ Universidade Federal do Paraná/UFPR, Programa de Pós-Graduação em Engenharia Florestal, Departamento de Engenharia Florestal, Avenida Prefeito Lothário Meissner, 900, Jardim Botânico, 80210-170 Curitiba, PR, Brazil

${ }^{2}$ Fundação Universidade Regional de Blumenau/FURB, Centro de Ciências Exatas e Naturais, Departamento de Ciências Naturais, Rua Antônio da Veiga, 140, Victor Konder, 89012-900 Blumenau, SC, Brazil

${ }^{3}$ Universidade Federal do Paraná/UFPR, Setor de Ciências Agrárias, Departamento de Engenharia Florestal, Avenida Prefeito Lothário Meissner, 900, Jardim Botânico, 80210-170 Curitiba, PR, Brazil

${ }^{4}$ Fundação Universidade Regional de Blumenau/FURB, Centro de Ciências Tecnológicas, Departamento de Engenharia Florestal, Rua São Paulo, 3250, Itoupava Seca, 89010-971 Blumenau, SC, Brazil
\end{abstract}

Manuscript received on March 6, 2017; accepted for publication on June 23, 2017

\begin{abstract}
Studies about dispersal syndromes and spatial distribution can provide information about species ecology. However, few studies analyze these ecological patterns in different vegetation layers. In this work, we verified the relationship between the dispersion syndromes and the spatial distribution in different layers in Araucaria Forest. We sampled 180 plots with size and inclusion criteria that changed according to the vegetative layer. We sampled 15,545 individuals in 103 tree species. We found significant differences between the number of species in the dispersion syndromes $\left(\chi^{2}=11.52 ; P \leq 0.05\right)$ and spatial distribution patterns $\left(\chi^{2}=10.94 ; P \leq 0.05\right)$, being zoochoric and tends to clustering the most predominant. We also found a significant interaction between the dispersion syndromes and spatial distribution patterns in the analyzed layers $(F=1,044 ; P<0.0001)$, with anemochoric species characterized by random distribution, autochoric in the cluster distribution and zoochoric in the tends to clustering. The results demonstrate that the tree species of the different layers are related to the type of dispersion and the aggregation pattern.
\end{abstract}

Key words: Araucaria forest, seed dispersal, spatial distribution, layers analysis.

\section{INTRODUCTION}

The Atlantic Forest hotspot covered $\sim 1,300,000$ $\mathrm{km}^{2}$ of Brazilian territory and also a small portion of Argentina - 9,950 $\mathrm{km}^{2}$ (Chebez and Hilgert 2003, De Angelo 2009) and Paraguay - 11,618

Correspondence to: João Paulo de Maçaneiro

E-mail: jpmacaneiro@gmail.com

* Contribution to the centenary of the Brazilian Academy of Sciences. $\mathrm{km}^{2}$ (Cartes and Yanosky 2003, Huang et al. 2007, 2009). It has high biodiversity (Stehmann et al. 2009), but, due to a historical process of 500 years of deforestation, it is currently highly fragmented, with only $11.7 \%$ of its original covering in Brazil (Ribeiro et al. 2011). Currently, the destruction of these forests for urban expansion and agricultural frontiers has resulted in high levels of fragmentation and threat to biodiversity (Tabarelli et al. 2010). 
The fragmentation process in tropical and subtropical forests, change natural habitats, limit seed dispersal and provide aggregation of tree species, as well as promote a high loss of fauna and flora diversity due to the structural complexity of these forests (Nathan and Muller-Landau 2000, Padilha et al. 2015). Changes in habitats may, for example, reflect on the decline of populations of frugivorous animals (Cox and Kesler 2012), which are responsible for $80 \%$ of seed dispersion in forest canopy species (Beckman and Rogers 2013). Another consequence of the fragmentation is the strong tendency of aggregation of the tree species, because in the absence of disperser agents, the seeds tend to fall closer to its mother plant (Wilson et al. 2004, Nathan 2006), as well as their reproductive isolation and consequent reduction of genetic diversity (Reis et al. 2012).

For many tree species, the spatial distribution pattern is strongly correlated with seed morphology, since it differs in its ability to disperse seeds (Seidler and Plotkin 2006). In old growth tropical and subtropical forests, between 50 and $75 \%$ of tree species produce fleshy fruits, which facilitates the animal feeding (Beckman and Rogers 2013, Traveset et al. 2014). This dispersion by animals can lead to occasional accumulations of propagules, due to their behavior (Schupp et al. 2002). On the other hand, the diaspore of wind-dispersed species tends to travel long distances from its mother plant and the success of the dispersal is conditioned by the wind intensity and forest canopy pattern (Nathan and Katul 2005).

The Araucaria Forest comprises a large part of southern plateau (Klein 1960, IBGE 2012, Kersten et al. 2015), and it is the greatest phytogeographic unit in extension and the most fragmented in the Brazilian Atlantic Forest. Araucaria forests originally occupied $42,851 \mathrm{~km}^{2}$ of the state of Santa Catarina (Klein 1978), but due to the intense fragmentation process it is currently reduced to only $24.4 \%$ of its original covering (Vibrans et al. 2012). In addition, these remnants are largely represented by fragments of secondary forests in the intermediate and late stages of regeneration, with rare primary or initial forests (Sevegnani et al. 2012, Vibrans et al. 2013, Maçaneiro et al. 2015, Maçaneiro et al. 2016a).

Considering the current state of Araucaria Forest's fragmentation in Santa Catarina (see Vibrans et al. 2012), studies that analyze the correlation between dispersal syndromes and spatial distribution patterns are significant since they can provide information on the conservation status of the current remnants and on the autoecology of plant species (Cousens et al. 2008). In this sense, we analyzed the relationship between the dispersion syndromes and the spatial distribution patterns of Araucaria Forest in Southern Brazil, in order to contribute to the tree species' population ecology and answer the following questions: i) Does the strategy of seed dispersal in the Araucaria Forest reflect the pattern of spatial distribution of tree species? ii) Are there differences between the forest layers with the dispersion syndromes and the patterns of spatial distribution of tree species?

\section{MATERIALS AND METHODS}

\section{STUDY AREA}

The study area is located in RPPN Emilio Einsfeld Filho, Campo Belo do Sul, Santa Catarina, Southern Brazil with 6,328.60 ha and altitude ranging from 620 to $980 \mathrm{~m}$, between $27^{\circ} 55^{\prime}$ and $28^{\circ} 05^{\prime} \mathrm{S}$ and $50^{\circ} 55^{\prime}$ and $50^{\circ} 44^{\prime} \mathrm{W}$. The climate, according to Köppen's classification (Alvares et al. 2014), is Cfb - temperate oceanic climate, without dry season and with temperate summer. The average annual temperature varies between $16-17^{\circ} \mathrm{C}$, with monthly averages between $11^{\circ} \mathrm{C}$ in the coldest month (July) and, $21^{\circ} \mathrm{C}$ in the hottest month (February). The annual relative moisture varies between $78-80 \%$ and, the total annual rainfall is well distributed 
with 1,527 $\mathrm{mm}$ throughout the year (Pandolfo et al. 2002).

The study area vegetation is constituted by Araucaria Forest (also called as Mixed Ombrophilous Forest - IBGE 2012), mainly characterized by dense presence of Brazilian pine [Araucaria angustifolia (Bertol.) Kuntze]. The area was used for logging until 1985, and this exploration concentrated on the Brazilian pine and other species of economic interest (like Ocotea porosa (Nees \& Mart.) Barroso, Ocotea odorifera (Vell.) Rohwer and Cedrela fissilis Vell.). Currently, the forest in the study area is characterized by degraded vegetation remnants due to selective use in the past. (Maçaneiro et al. 2016b) and characterized as a continuous fragment formed by corridors, especially through the river system.

\section{DATA COLLECTION}

We divided the vegetation in three layers: 1) upper tree layer (UTL); 2) lower tree layer (LTL) and, 3) natural regeneration (NR). In the first two layers, tree individuals have reached maturity and in the third layer, the plants are in the process of natural regeneration. We randomly assigned 180 plots of $10 \times 50 \mathrm{~m}\left(500 \mathrm{~m}^{2}\right)$ (including palms and tree ferns) with diameter at breast height $(\mathrm{DBH}) \geq 10$ $\mathrm{cm}$ for UTS. In each part of the UTL we added a subplot of $10 \times 25 \mathrm{~m}\left(250 \mathrm{~m}^{2}\right)$, to access the LTL, characterized by individuals with $5 \mathrm{~cm} \leq \mathrm{DBH}<10$ $\mathrm{cm}$. For the NR survey, a circular plot with $2.5 \mathrm{~m}$ radius was inserted in the center of each UTL plot $\left(19.6 \mathrm{~m}^{2}\right)$, where we sampled all individuals with height $\geq 50 \mathrm{~cm}$ and $\mathrm{DBH}<5 \mathrm{~cm}$. These plots were randomized and installed at a minimum distance of $20 \mathrm{~m}$ from the forest edge.

The botanical material was identified in the Laboratory of Dendrology and Dr. Roberto Miguel Klein Herbarium (FURB), from the Universidade Regional de Blumenau (FURB), as well as in available literature. We followed APG IV and PPG
I for species classification (APG IV 2016, PPG I 2016) and Brazilian Flora 2020 (2017) for scientific names.

\section{DATA ANALYSIS}

We classified the species as anemochoric, autochoric and zoochoric, following Pijl (1982), based on Araucaria Forest studies, such as Paise and Vieira (2005), Almeida et al. (2008), Liebsch and Mikich (2009), Liebsch et al. (2009), Klauberg et al. (2010), Negrini et al. (2012) and Ferreira et al. (2013).

We calculated, for each population, the McGuinnes index, to analyze the distribution pattern. This index is based on the relationship between the observed density and the expected density of individuals of a given species in the sample (McGuinnes 1934). Thus, when the value is $<1$ the distribution of the species is uniform; when it is equal to 1 the distribution is random; when it is $>1$ and $\leq 2$ the distribution tends to cluster and; when $>2$ the distribution is clustered.

In order to verify if the dispersion syndromes and spatial distribution patterns differ in the analyzed layers, a partitioned chi-square test was applied using a level of significance $\alpha=0.05$. Then, the existence of interaction between the dispersion syndromes and the spatial distribution patterns was tested through two-way ANOVA. In this analysis, the number of individuals of each species in the plots was considered, and a significance level of $\alpha=0.05$ was applied. We tested the assumptions of normality, homoscedasticity and randomness (Zar 2010).

\section{RESULTS}

We sampled 15,545 individuals, belonging to 103 species, 76 genera and 44 families (Tables I and II). Myrtaceae had the highest richness (16 species), followed by Fabaceae and Lauraceae ( 7 species each); Euphorbiaceae, Rutaceae, Sapindaceae and Solanaceae (5 species each). 
TABLE I

Analyzed parameters for the species in different layers of Araucaria Forest in Southern Brazil.

\begin{tabular}{|c|c|c|c|}
\hline Parameters & $\begin{array}{c}\text { Upper } \\
\text { tree layer }\end{array}$ & $\begin{array}{c}\text { Lower } \\
\text { tree layer }\end{array}$ & $\begin{array}{c}\text { Natural } \\
\text { regeneration }\end{array}$ \\
\hline $\begin{array}{l}\text { Sample area } \\
\left(\mathrm{m}^{2}\right)\end{array}$ & $90,000.00$ & $45,000.00$ & $3,534.30$ \\
\hline Species number & 98 & 85 & 89 \\
\hline Genus number & 72 & 67 & 66 \\
\hline Families number & 40 & 38 & 40 \\
\hline $\begin{array}{l}\text { Individual } \\
\text { number }\end{array}$ & 8,362 & 3,105 & 4,078 \\
\hline $\begin{array}{l}\text { Tree density } \\
\left(\text { ind }^{-1} \mathrm{ha}^{-1} \text { ) }\right.\end{array}$ & 929.1 & 690.0 & $11,538.4$ \\
\hline $\begin{array}{l}\text { Basal area } \\
\left(\mathrm{m}^{2} \cdot \mathrm{ha}^{-1}\right)\end{array}$ & 42.77 & 2.68 & - \\
\hline
\end{tabular}

There were significant differences in the species dispersion syndromes and spatial distribution patterns in the analyzed layers (dispersion syndromes: $\chi^{2}=11.52 ; p \leq 0.05$; spatial distribution patterns: $\left.\chi^{2}=10.94 ; p \leq 0.05\right)$. Zoochoric is the most common syndrome $(\mathrm{UTL}=69.4 \%$, LTL $=$ $70.6 \%$ and $\mathrm{NR}=70.8 \%$ ) with a tends to cluster the most common distribution pattern (UTL $=71.1 \%$, $\mathrm{LTL}=54.1 \%$ and $\mathrm{NR}=58.4 \%$ ) (Figure 1$)$.
There are significant interaction (ANOVA, $F=1,044 ; p<0.0001)$ between the dispersion syndromes and the patterns of spatial distribution in all layers, indicating that the species are influenced by these ecological characteristics (Figure 2). In the zoochoric species, more than $75 \%$ have tends to cluster spatial distribution.

\section{DISCUSSION}

Our results show that the dispersion syndromes and the patterns of spatial distribution of tree species vary according to the forest layer. In addition, the distribution of tree species is conditioned by the dispersion syndrome and the aggregation pattern. Regarding the dispersion syndromes, the prevalence of zoocoria is expected for the Araucaria Forest, occurring with greater intensity in the forest's lower layers where it can represent up to $80 \%$ of the tree species (Foster 1982, Beckman and Rogers 2013). In the present study, the high richness of zoochoric species may be an indication that the forest is in its late stage of regeneration, since the
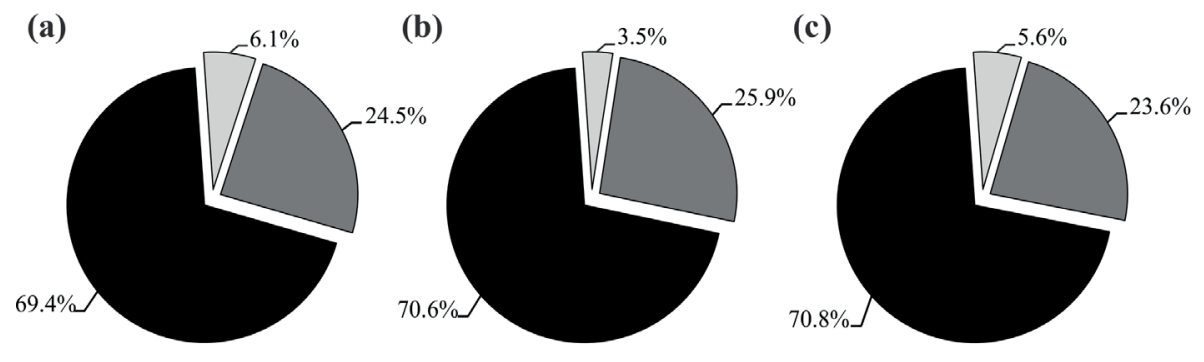

$\square$ Autochoric $\square$ Anemochoric $\quad$ Zoochoric

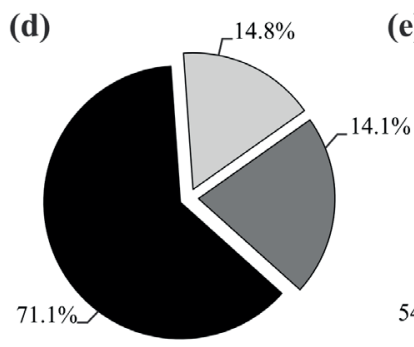

(e)

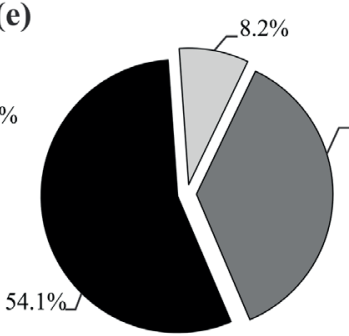

(f)

$\square$ Clustered $\quad \square$ Random $\quad$ Tends to cluster

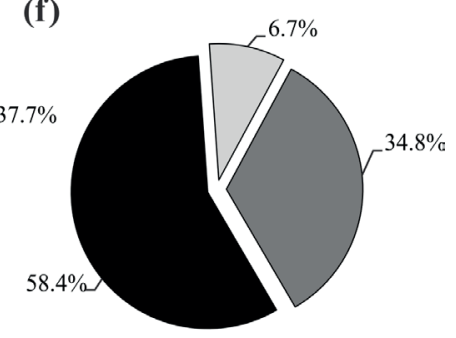

Figure 1 - Dispersion syndrome (\%) and spatial distribution pattern (\%) for upper tree layer (a, d); lower tree layer (b, e) and natural regeneration (c, f) of Araucaria Forest in Southern Brazil. 
Table II

Families and species sampled in different layers of Araucaria Forest in Southern Brazil. SD = dispersion syndrome; An = anemochoric; $A u=$ autochoric; $Z$ Zo = zoochoric; $U T L=$ upper tree layer; $L T L=$ lower tree layer; $N R=$ natural regeneration; * = Species absent in the layer; $\mathbf{C}=$ clustered; $\mathbf{R}=$ random; $\mathbf{T c}=$ tends to cluster.

\begin{tabular}{|c|c|c|c|c|c|c|c|c|}
\hline \multirow{2}{*}{ Families } & \multirow{2}{*}{ Species } & \multirow{2}{*}{ SD } & \multicolumn{3}{|c|}{ McGuinnes index } & \multicolumn{3}{|c|}{ Spatial distribution } \\
\hline & & & UTL & LTL & NR & UTL & LTL & NR \\
\hline Adoxaceae & $\begin{array}{l}\text { Sambucus australis Cham. \& } \\
\text { Schltdl. }\end{array}$ & Zo & 1.49 & $*$ & $*$ & Tc & $*$ & $*$ \\
\hline \multirow[t]{3}{*}{ Anacardiaceae } & Lithrea brasiliensis Marchand & Zo & 3.22 & 1.51 & $*$ & $\mathrm{C}$ & $\mathrm{Tc}$ & $*$ \\
\hline & Schinus lentiscifolia Marchand & Zo & 1.18 & 1.00 & $*$ & $\mathrm{Tc}$ & $\mathrm{R}$ & $*$ \\
\hline & Schinus terebinthifolia Raddi & Zo & 2.99 & 1.00 & 1.00 & $\mathrm{C}$ & $\mathrm{R}$ & $\mathrm{R}$ \\
\hline Annonaceae & $\begin{array}{l}\text { Annona emarginata (Schltdl.) } \\
\text { H.Rainer }\end{array}$ & Zo & 1.21 & 1.42 & 1.39 & Tc & Tc & $\mathrm{Tc}$ \\
\hline Apocynaceae & Aspidosperma tomentosum Mart. & An & 2.99 & 1.00 & 1.00 & $\mathrm{C}$ & $\mathrm{R}$ & $\mathrm{R}$ \\
\hline \multirow[t]{2}{*}{ Aquifoliaceae } & Ilex dumosa Reissek & Zo & 1.65 & $*$ & $*$ & $\mathrm{Tc}$ & $*$ & $*$ \\
\hline & Ilex theezans Mart. ex Reissek & Zo & 1.99 & 1.00 & 1.32 & $\mathrm{Tc}$ & $\mathrm{R}$ & Tc \\
\hline Araucariaceae & $\begin{array}{l}\text { Araucaria angustifolia (Bertol.) } \\
\text { Kuntze }\end{array}$ & Zo & 1.94 & 1.41 & 1.40 & $\mathrm{Tc}$ & $\mathrm{Tc}$ & $\mathrm{Tc}$ \\
\hline Arecaceae & $\begin{array}{l}\text { Syagrus romanzoffiana (Cham.) } \\
\text { Glassman }\end{array}$ & Zo & 1.51 & 1.00 & 1.47 & Tc & $\mathrm{R}$ & $\mathrm{Tc}$ \\
\hline \multirow[t]{4}{*}{ Asteraceae } & Baccharis uncinella DC. & An & $*$ & 1.00 & * & $*$ & $\mathrm{R}$ & $*$ \\
\hline & $\begin{array}{l}\text { Moquiniastrum polymorphum } \\
\text { (Less.) G. Sancho }\end{array}$ & An & 1.85 & 1.00 & 1.00 & $\mathrm{Tc}$ & $\mathrm{R}$ & $\mathrm{R}$ \\
\hline & $\begin{array}{l}\text { Piptocarpha angustifolia Dusén ex } \\
\text { Malme }\end{array}$ & An & 2.26 & 1.99 & 1.00 & $\mathrm{C}$ & Tc & $\mathrm{R}$ \\
\hline & $\begin{array}{l}\text { Vernonanthura discolor (Spreng.) } \\
\text { H.Rob. }\end{array}$ & An & 1.99 & 1.00 & 1.00 & $\mathrm{Tc}$ & $\mathrm{R}$ & $\mathrm{R}$ \\
\hline \multirow[t]{2}{*}{ Bignoniaceae } & $\begin{array}{l}\text { Handroanthus catarinensis } \\
\text { (A.H.Gentry) S.Grose }\end{array}$ & An & 1.00 & 1.00 & 1.00 & $\mathrm{R}$ & $\mathrm{R}$ & $\mathrm{R}$ \\
\hline & Jacaranda micrantha Cham. & An & 1.70 & 1.38 & 1.00 & $\mathrm{Tc}$ & Tc & $\mathrm{R}$ \\
\hline Boraginaceae & $\begin{array}{l}\text { Cordia americana (L.) Gottschling } \\
\text { \& J.S.Mill. }\end{array}$ & An & 1.15 & 1.00 & 1.00 & Tc & $\mathrm{R}$ & $\mathrm{R}$ \\
\hline Canellaceae & Cinnamodendron dinisii Schwacke & Zo & 2.34 & 1.42 & 1.53 & $\mathrm{C}$ & $\mathrm{Tc}$ & Tc \\
\hline Cardiopteridaceae & $\begin{array}{l}\text { Citronella gongonha (Mart.) } \\
\text { R.A.Howard }\end{array}$ & Zo & 1.10 & 1.26 & 1.31 & $\mathrm{Tc}$ & Tc & $\mathrm{Tc}$ \\
\hline Celastraceae & Maytenus aquifolia Mart. & Zo & 1.26 & 1.12 & 1.00 & Tc & $\mathrm{Tc}$ & $\mathrm{R}$ \\
\hline Clethraceae & Clethra scabra Pers. & $\mathrm{Au}$ & 1.00 & $*$ & 1.00 & $\mathrm{R}$ & $*$ & $\mathrm{R}$ \\
\hline \multirow[t]{2}{*}{ Cunoniaceae } & Lamanonia ternata Vell. & An & 1.84 & 1.32 & 1.00 & $\mathrm{Tc}$ & Tc & $\mathrm{R}$ \\
\hline & Weinmannia humilis Engl. & An & 1.00 & 1.00 & 1.00 & $\mathrm{R}$ & $\mathrm{R}$ & $\mathrm{R}$ \\
\hline Cyatheaceae & Alsophila setosa Kaulf. & An & 1.76 & 1.24 & 1.16 & $\mathrm{Tc}$ & Tc & Tc \\
\hline Dicksoniaceae & Dicksonia sellowiana Hook. & An & 4.11 & 1.00 & 3.50 & $\mathrm{C}$ & $\mathrm{R}$ & $\mathrm{C}$ \\
\hline Erythroxylaceae & $\begin{array}{l}\text { Erythroxylum argentinum } \\
\text { O.E.Schulz }\end{array}$ & Zo & 1.41 & 1.00 & 1.00 & Tc & $\mathrm{R}$ & $\mathrm{R}$ \\
\hline Escalloniaceae & Escallonia bifida Link \& Otto & An & 1.49 & $*$ & 1.00 & $\mathrm{Tc}$ & $*$ & $\mathrm{R}$ \\
\hline \multirow[t]{3}{*}{ Euphorbiaceae } & ** Aleurites moluccana (L.) Willd. & Zo & 1.49 & 1.24 & 1.00 & $\mathrm{Tc}$ & $\mathrm{Tc}$ & $\mathrm{R}$ \\
\hline & $\begin{array}{l}\text { Bernardia pulchella (Baill.) Müll. } \\
\text { Arg. }\end{array}$ & Zo & 1.13 & 1.00 & 1.10 & Tc & $\mathrm{R}$ & Tc \\
\hline & Sapium glandulosum (L.) Morong & $\mathrm{Au}$ & 3.12 & 1.77 & 2.17 & $\mathrm{C}$ & $\mathrm{Tc}$ & $\mathrm{C}$ \\
\hline
\end{tabular}


TABLE II (continuation)

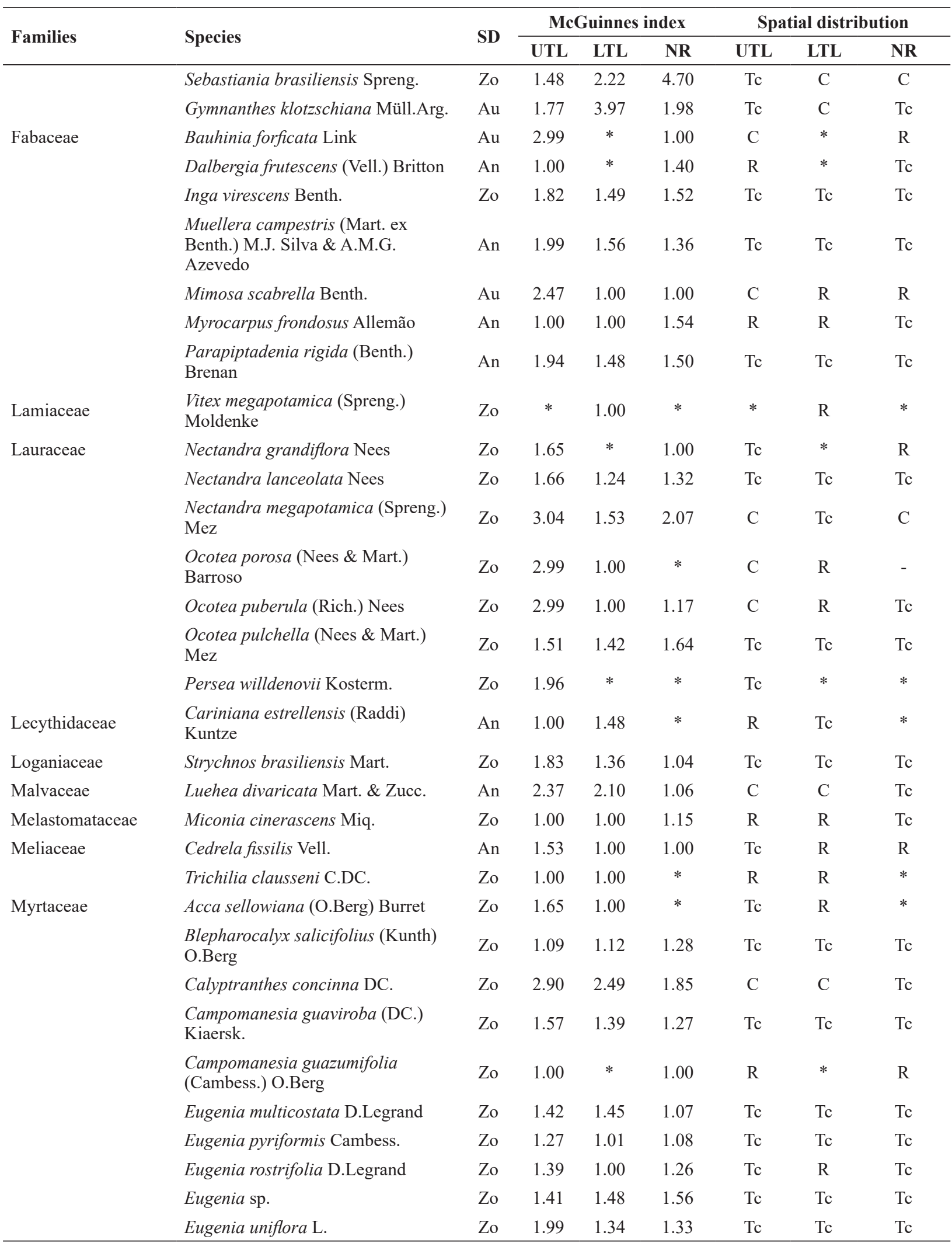


TABLE II (continuation)

\begin{tabular}{|c|c|c|c|c|c|c|c|c|}
\hline \multirow{2}{*}{ Families } & \multirow{2}{*}{ Species } & \multirow{2}{*}{ SD } & \multicolumn{3}{|c|}{ McGuinnes index } & \multicolumn{3}{|c|}{ Spatial distribution } \\
\hline & & & UTL & LTL & NR & UTL & LTL & NR \\
\hline & Myrceugenia sp. & Zo & 1.59 & 1.02 & 1.35 & $\mathrm{Tc}$ & $\mathrm{Tc}$ & $\mathrm{Tc}$ \\
\hline & Myrcia hatschbachii D.Legrand & Zo & 1.00 & $*$ & 1.00 & $\mathrm{R}$ & $*$ & $\mathrm{R}$ \\
\hline & Myrcia palustris DC. & Zo & 1.24 & 1.10 & 1.29 & $\mathrm{Tc}$ & $\mathrm{Tc}$ & $\mathrm{Tc}$ \\
\hline & Myrcia selloi (Spreng.) N.Silveira & Zo & 1.00 & $*$ & 1.00 & $\mathrm{R}$ & $*$ & $\mathrm{R}$ \\
\hline & Myrcia sp. & Zo & 1.17 & 1.01 & 1.49 & $\mathrm{Tc}$ & $\mathrm{Tc}$ & $\mathrm{Tc}$ \\
\hline & $\begin{array}{l}\text { Myrcianthes pungens (O.Berg) } \\
\text { D.Legrand }\end{array}$ & Zo & 1.11 & 1.21 & 1.45 & $\mathrm{Tc}$ & $\mathrm{Tc}$ & $\mathrm{Tc}$ \\
\hline Peraceae & $\begin{array}{l}\text { Pera glabrata (Schott) Poepp. ex } \\
\text { Baill. }\end{array}$ & Zo & 2.54 & 1.07 & 1.00 & $\mathrm{C}$ & $\mathrm{Tc}$ & $\mathrm{R}$ \\
\hline \multirow[t]{2}{*}{ Phytolaccaceae } & Seguieria aculeata Jacq. & An & 1.74 & 1.36 & 1.38 & $\mathrm{Tc}$ & $\mathrm{Tc}$ & $\mathrm{Tc}$ \\
\hline & Seguieria langsdorffii Moq. & An & 1.00 & $*$ & $*$ & $\mathrm{R}$ & $*$ & $*$ \\
\hline Podocarpaceae & $\begin{array}{l}\text { Podocarpus lambertii Klotzsch ex } \\
\text { Endl. }\end{array}$ & Zo & 1.64 & 1.31 & 1.50 & $\mathrm{Tc}$ & $\mathrm{Tc}$ & $\mathrm{Tc}$ \\
\hline \multirow[t]{3}{*}{ Primulaceae } & $\begin{array}{l}\text { Myrsine coriacea (Sw.) R.Br. ex } \\
\text { Roem. \& Schult. }\end{array}$ & Zo & 1.96 & 1.90 & 1.68 & $\mathrm{Tc}$ & $\mathrm{Tc}$ & $\mathrm{Tc}$ \\
\hline & Myrsine lancifolia Mart. & Zo & $*$ & $*$ & 1.99 & * & $*$ & $\mathrm{Tc}$ \\
\hline & Myrsine umbellata Mart. & Zo & 3.22 & 1.31 & 1.00 & $\mathrm{C}$ & $\mathrm{Tc}$ & $\mathrm{R}$ \\
\hline Proteaceae & $\begin{array}{l}\text { Roupala montana var. brasiliensis } \\
\text { (Klotzch) K.S.Edwards }\end{array}$ & An & 1.52 & 1.00 & 1.47 & $\mathrm{Tc}$ & $\mathrm{R}$ & $\mathrm{Tc}$ \\
\hline Quillajaceae & $\begin{array}{l}\text { Quillaja brasiliensis (A.St.-Hil. \& } \\
\text { Tul.) Mart. }\end{array}$ & An & 1.23 & 1.00 & $*$ & $\mathrm{Tc}$ & $\mathrm{R}$ & $*$ \\
\hline \multirow[t]{2}{*}{ Rosaceae } & $\begin{array}{l}\text { Prunus brasiliensis (Cham. \& } \\
\text { Schltdl.) D.Dietr. }\end{array}$ & Zo & 1.80 & $*$ & 1.99 & $\mathrm{Tc}$ & $*$ & $\mathrm{Tc}$ \\
\hline & Prunus myrtifolia (L.) Urb. & Zo & 1.24 & 1.15 & 1.07 & $\mathrm{Tc}$ & $\mathrm{Tc}$ & $\mathrm{Tc}$ \\
\hline Rubiaceae & $\begin{array}{l}\text { Rudgea parquioides (Cham.) Müll. } \\
\text { Arg. }\end{array}$ & Zo & * & $*$ & 1.28 & $*$ & $*$ & $\mathrm{Tc}$ \\
\hline \multirow[t]{5}{*}{ Rutaceae } & Helietta apiculata Benth. & An & 1.86 & 1.13 & 1.67 & $\mathrm{Tc}$ & $\mathrm{Tc}$ & $\mathrm{Tc}$ \\
\hline & Pilocarpus pennatifolius Lem. & $\mathrm{Au}$ & 1.00 & $*$ & $*$ & $\mathrm{R}$ & $*$ & $*$ \\
\hline & $\begin{array}{l}\text { Zanthoxylum kleinii (R.S.Cowan) } \\
\text { P.G.Waterman }\end{array}$ & Zo & 1.62 & 1.00 & 1.00 & $\mathrm{Tc}$ & $\mathrm{R}$ & $\mathrm{R}$ \\
\hline & $\begin{array}{l}\text { Zanthoxylum petiolare A.St.-Hil. } \\
\text { \& Tul. }\end{array}$ & Zo & 1.00 & 1.00 & 1.00 & $\mathrm{R}$ & $\mathrm{R}$ & $\mathrm{R}$ \\
\hline & Zanthoxylum rhoifolium Lam. & Zo & 1.30 & 1.41 & 1.00 & $\mathrm{Tc}$ & $\mathrm{Tc}$ & $\mathrm{R}$ \\
\hline \multirow[t]{4}{*}{ Salicaceae } & Casearia decandra Jacq. & Zo & 1.58 & 1.55 & 1.54 & $\mathrm{Tc}$ & $\mathrm{Tc}$ & $\mathrm{Tc}$ \\
\hline & Casearia obliqua Spreng. & Zo & 1.45 & 1.37 & 1.11 & $\mathrm{Tc}$ & $\mathrm{Tc}$ & $\mathrm{Tc}$ \\
\hline & Casearia sylvestris Sw. & Zo & 1.00 & 3.99 & 1.00 & $\mathrm{R}$ & $\mathrm{C}$ & $\mathrm{R}$ \\
\hline & Xylosma ciliatifolia (Clos) Eichler & Zo & 1.71 & 1.72 & 1.25 & $\mathrm{Tc}$ & $\mathrm{Tc}$ & $\mathrm{Tc}$ \\
\hline \multirow[t]{4}{*}{ Sapindaceae } & $\begin{array}{l}\text { Allophylus edulis (A.St.-Hil. et al.) } \\
\text { Hieron. ex Niederl. }\end{array}$ & Zo & 1.32 & 1.46 & 1.70 & $\mathrm{Tc}$ & $\mathrm{Tc}$ & $\mathrm{Tc}$ \\
\hline & $\begin{array}{l}\text { Allophylus guaraniticus (A.St.-Hil.) } \\
\text { Radlk. }\end{array}$ & Zo & 1.99 & $*$ & 3.64 & $\mathrm{Tc}$ & $*$ & $\mathrm{C}$ \\
\hline & $\begin{array}{l}\text { Allophylus puberulus (Cambess.) } \\
\text { Radlk. }\end{array}$ & Zo & 1.49 & 1.17 & 2.30 & $\mathrm{Tc}$ & $\mathrm{Tc}$ & $\mathrm{C}$ \\
\hline & Cupania vernalis Cambess. & Zo & 2.85 & 2.57 & 1.55 & $\mathrm{C}$ & $\mathrm{C}$ & $\mathrm{Tc}$ \\
\hline
\end{tabular}


TABLE II (continuation)

\begin{tabular}{|c|c|c|c|c|c|c|c|c|}
\hline \multirow{2}{*}{ Families } & \multirow{2}{*}{ Species } & \multirow{2}{*}{ SD } & \multicolumn{3}{|c|}{ McGuinnes index } & \multicolumn{3}{|c|}{ Spatial distribution } \\
\hline & & & UTL & LTL & NR & UTL & LTL & NR \\
\hline \multirow{6}{*}{ Solanaceae } & Matayba elaeagnoides Radlk. & Zo & 2.43 & 1.98 & 1.37 & $\mathrm{C}$ & $\mathrm{Tc}$ & Tc \\
\hline & Brunfelsia pilosa Plowman & Zo & 1.00 & 1.00 & 1.26 & $\mathrm{R}$ & $\mathrm{R}$ & $\mathrm{Tc}$ \\
\hline & Capsicum flexuosum Sendtn. & Zo & 1.06 & 1.00 & 1.54 & $\mathrm{Tc}$ & $\mathrm{R}$ & $\mathrm{Tc}$ \\
\hline & Solanum mauritianum Scop. & Zo & 1.00 & 1.00 & 1.00 & $\mathrm{R}$ & $\mathrm{R}$ & $\mathrm{R}$ \\
\hline & Solanum sanctaecatharinae Dunal & Zo & 1.97 & 2.54 & 1.18 & $\mathrm{Tc}$ & $\mathrm{C}$ & $\mathrm{Tc}$ \\
\hline & Solanum sp. & Zo & 1.00 & 1.00 & 1.00 & $\mathrm{R}$ & $\mathrm{R}$ & $\mathrm{R}$ \\
\hline Styracaceae & Styrax leprosus Hook. \& Arn. & Zo & 2.38 & 1.45 & 1.60 & $\mathrm{C}$ & $\mathrm{Tc}$ & Tc \\
\hline Thymelaeaceae & Daphnopsis racemosa Griseb. & Zo & $*$ & $*$ & 1.00 & $*$ & $*$ & $\mathrm{R}$ \\
\hline Winteraceae & Drimys brasiliensis Miers & Zo & 1.48 & 1.24 & 1.32 & $\mathrm{Tc}$ & $\mathrm{Tc}$ & Tc \\
\hline
\end{tabular}

** Alien species.
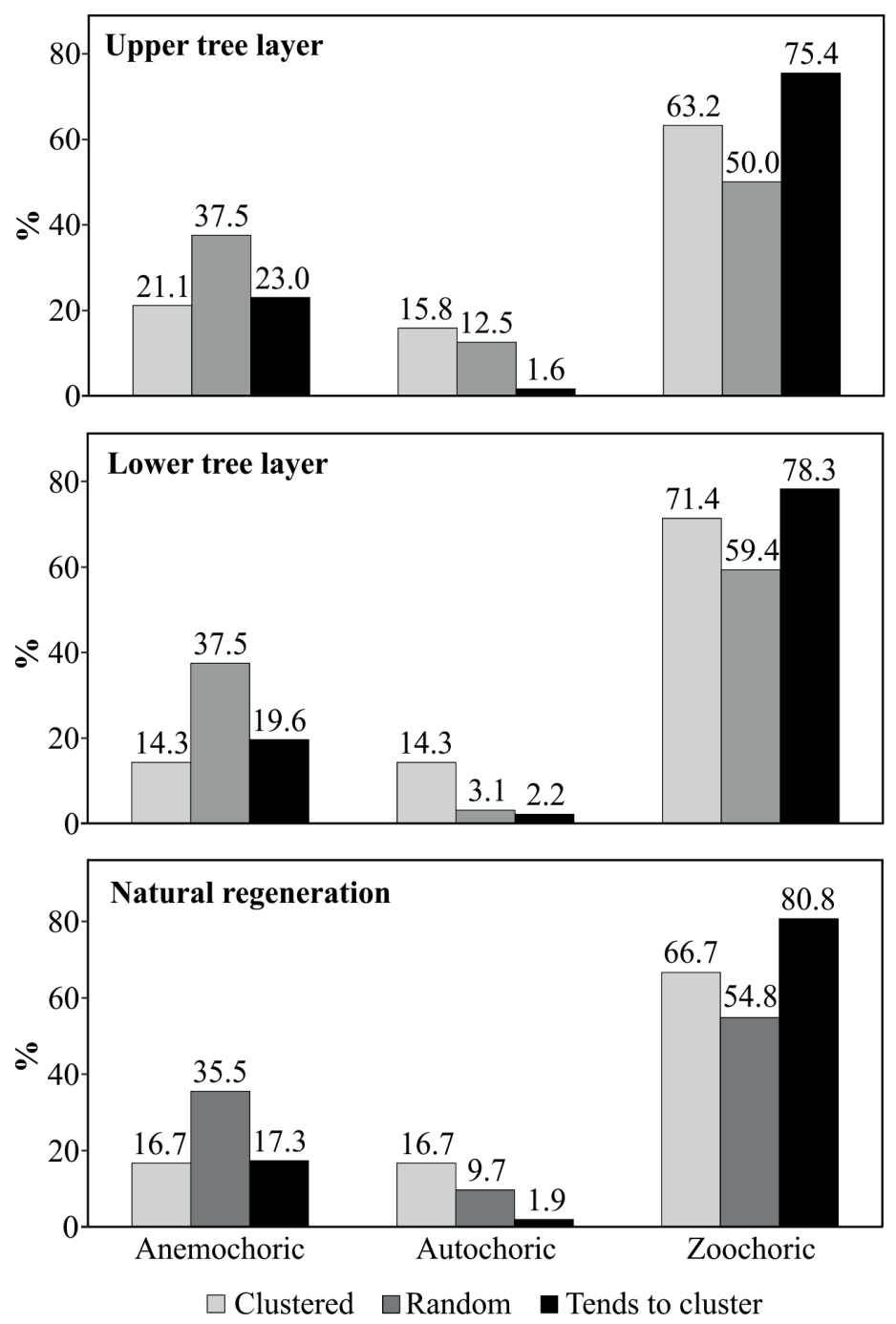

Figure 2 - Species spatial distribution pattern by dispersion syndrome in different layers of an Araucaria Forest in Southern Brazil. 
proportion of zoochoric species tends to increase according to the progression in the successional process (Liebsch et al. 2008). The Myrtaceae, Lauraceae and Sapindaceae families are generally identified as the most important of the Araucaria Forest in Santa Catarina (Klein 1978, Gasper et al. 2013), mainly because it represents a great part of the species with zoochoric dispersion (Liebsch and Mikich 2009, Klauberg et al. 2010, Negrini et al. 2012). These families are also typical of wellconserved forests and exhibit the characteristic of high abundance of individuals under the Araucaria Forest canopy, which are an important source of resources for the frugivorous animals (Klein 1960, Reitz and Klein 1966, Paise and Vieira 2005).

Most species in the analyzed layers tend to cluster in the forest. This characteristic has already been reported for $65 \%$ of the species by Kanieski et al. (2012). However, regenerating species may have a tends to cluster and, adult trees to occur in groups (see Nascimento et al. 2001). This may occur due to the interactions with the dispersing agents or because of a density-dependent competition increase, where population fluctuations of plants depend directly on the size of the previous population, which in turn is determined by intrinsic ecological processes (see Berryman 1999, Knape and Valpine 2012). For example, Beckman and Rogers (2013) mention that some animals can deposit seeds in favorable environments for their germination (clearings, tree trunks, forest edges), or even in the same place, as in the case of tapirs (Giombini et al. 2009), where they generate an aggregate pattern of palm Syagrus romanzoffiana (Cham.) Glassman. Boyer et al. (2006) point out that some primates follow mental maps and choose their path according to a criterion of maximum efficiency to find scarce resources (fruits and seeds) in a heterogeneous environment, such as tropical forests. These animals may deposit seeds in aggregate at some sites, however, the foraging patterns are generalized and seed dispersal in the forest may be random (Boyer et al. 2006).
Furthermore, the aggregation pattern of many tree species will depend on the secondary dispersion event, promoted by insects or rodents on the soil (Forget et al. 2005, Vander Wall et al. 2005, Silva et al. 2012). For example, the aggregation of seeds dispersed by animals at specific sites depends on the number of seeds per defecation, the aggregation of defecations and the persistence of seed entering the deposition sites over time, among others (Beckman and Rogers, 2013). In altered secondary forests, the tendency of aggregation of zoochoric species may occur due to habitat fragmentation, for absence of dispersant animals the seeds of the trees tend to be dispersed near the mother plant (Wilson et al. 2004, Nathan 2006). However, in well-conserved secondary forests where dispersal animals are present, seed aggregation may occur in greater proportion under nests or along paths used by animals that travel small and long distances (Schupp et al. 2002, Boyer et al. 2006) and in environments similar to the mother plant (Cavallero et al. 2012). In the present study, several ecological factors may be contributing to the aggregation of zoochoric species (see Boyer et al. 2006, Beckman and Rogers 2013). However, detailed studies on the interactions between dispersing agents and tree species should be performed to confirm this hypothesis.

The anemochoric dispersion was characterized by the predominance of species with random distribution. In forest ecosystems, this result is usually expected, since the seeds of anemochoric species have winged structures that favor transport by the wind (Barbosa et al. 2012). Moreover, these seeds can reach long distances from their point of origin according to the intensity of the wind and the distribution of treetops (Nathan et al. 2001, Beckman and Rogers 2013). The higher proportion of anemochoric species with a random distribution suggests that these species, once dispersed by the wind and not having a specific place for their deposit, are randomly distributed in all forest layers. 
The clustered distribution was the most representative in autochoric species. These species have explosive mechanisms of dispersion or are dispersed by gravity (Barbosa et al. 2012), in addition to having small dispersion distance in relation to other means, which results in a high density of seeds and seedlings near the mother plant (Narbona et al. 2005, Nathan 2006). Due to these ecological traits, generally autochoric species tend to present a clustered distribution pattern (Ricklefs 2010, Barbosa et al. 2012). However, although autochoric is uncommon in Neotropical forests (see Howe and Smallwood 1982, Talora and Morellato 2000, Barbosa et al. 2012), these species are important for forest fragments regeneration. For example, Lopes et al. (2012) verified that, in the absence of anemochoric and zoochoric species, the succession of fragmented forests is driven by the dynamics of some autochoric species, which gradually move to more distant places. The results show that the species of different layers of forest are related to the type of dispersion and the aggregation pattern, since the existence of a significant interaction between the dispersion syndromes and the spatial distribution patterns was verified. The distribution of the dispersion syndromes and the spatial distribution patterns of the species presented significant differences in the analyzed layers and most of the species showed a zoochoric distribution and a tends to cluster distribution. The anemochoric species characterized the pattern of random distribution, followed by the autochoric species with clustered distribution pattern. We conclude that further studies on the dispersion and aggregation of tree species in neotropical forests take into account the interaction between these ecological traits.

\section{ACKNOWLEDGMENTS}

The authors are grateful to Universidade Regional de Blumenau, Universidade Federal do Paraná, and
Conselho Nacional de Desenvolvimento Científico e Tecnológico (CNPq) for their research fellowship grant (306216/2013-2 and 141232/2018-8). We also thank Luiz Henrique da Silva from FURB Idiomas and Daiana Vogel for English review.

\section{REFERENCES}

ALMEIDA SR, WATZLAWICK LF, MYSZKA E AND VALERIO AF. 2008. Plants and dispersal syndromes of a remanent Mixed Ombrophilous Forest in a field system. Ambiência 4: 289-297.

ALVARES CA, STAPE JL, SENTELHAS PC, GONÇALVEZ JLM AND SPAROVEK G. 2014. Köppen's climate classification map for Brazil. Meteorol Z 22: 711-728.

APG IV. 2016. An update of the Angiosperm Phylogeny Group classification for the orders and families of flowering plants: APG IV. Bot J Linn. Soc 181: 1-20.

BARBOSA JM, EISENLOHR PV, RODRIGUES MA AND BARBOSA KC. 2012. Ecologia da dispersão de sementes em florestas tropicais. In: Martins SV (Ed), Ecologia De Florestas Tropicais do Brasil, Viçosa: Editora UFV, p. 85106.

BECKMAN NG AND ROGERS HS. 2013. Consequences of seed dispersal for plant recruitment in tropical forests: interactions within the seedscape. Biotropica 45: 666-681.

BERRYMAN AA. 1999. Principles of population dynamics and their application. Cheltenham: Stanley Thornes, $256 \mathrm{p}$.

BOYER D, RAMOS-FERNÁNDEZ G, MIRAMONTES O, MATEOS JL, COCHO G, LARRALDE H, RAMOS H AND ROJAS F. 2006. Scale-free foraging by primates emerges from their interaction with a complex environment. Proc Biol Sci 273: 1743-1750.

BRAZILIAN FLORA. 2020. In construction. Rio de Janeiro Botanical Garden. Available in: < http://floradobrasil.jbrj. gov.br/ >. Accessed in: 21 Jun. 2017.

CARTES JL AND YANOSKY A. 2003. Dynamics of biodiversity loss in the Paraguayan Atlantic Forest: an introduction. In: Galindo-Lean C and Câmara IG (Eds), The Atlantic Forest of South America: biodiversity status, threats, and outlook. Washington: Island Press, p. 267-269.

CAVALLERO L, AIZEN MA AND RAFFAELE E. 2012. Endozoochory decreases environmental filtering imposed to seedlings. J Veg Sci 23: 677-689.

CHEBEZ JC AND HILGERT N. 2003. Brief history of conservation in the Paraná Forest. In: Galindo-Lean $\mathrm{C}$ and Câmara IG (Eds), The Atlantic Forest of South America: biodiversity status, threats, and outlook. Washington: Island Press, p. 141-159.

COUSENS R, DYTHAM C AND LAW R. 2008. Dispersal in plants: a population perspective. New York: Oxford University Press, 240 p. 
COX AS AND KESLER DC. 2012. Prospecting behavior and the influence of forest cover on natal dispersal in a resident bird. Behav Ecol 23: 1068-1077.

DE ANGELO C. 2009. El paisaje del Bosque Atlántico del Alto Paraná y sus efectos sobre la distribución y estructura poblacional del jaguar (Panthera onca) y el puma (Puma concolor), Buenos Aires: Universidad de Buenos Aires, $252 \mathrm{p}$.

FERREIRA PI, GOMES JP, BATISTA F, BERNARDI AP, COSTA NCF, BORTOLUZZI RLC AND MANTOVANI A. 2013. Potential species for recovery of permanent preservation areas in the highlands of Santa Catarina state, Brazil. Floresta Ambient 20: 173-182.

FOSTER RB. 1982. The seasonal rhythm of fruitfall on Barro Colorado Island. In: Leight EG et al. (Eds), The ecology of a tropical forest: seasonal rhytms and long-term changes. Washington: Smithsonian Institution Press, p. 151-172.

FORGET PM, LAMBERT JE, HULME PE AND VANDER WALL SB. 2005. Seed fate: Predation, dispersal and seedling establishment. Wallingford: CAB International, $432 \mathrm{p}$.

GASPER AL ET AL. 2013. Flora of the mixed ombrophyllous forest in Santa Catarina state, according of the forest and floristic inventory of Santa Catarina. Rodriguésia 62: 201210.

GIOMBINI MI, BRAVO SP AND MARTÍNEZ MF. 2009. Seed dispersal of the palm Syagrus romanzoffiana by tapirs in the Semi-deciduous Atlantic Forest of Argentina. Biotropica 41: 408-413.

HOWE HF AND SMALLWOOD J. 1982. Ecology of seed dispersal. Ann Rev Ecolog Syst 13: 201-228.

HUANG CQ ET AL. 2007. Rapid loss of Paraguay's Atlantic Forest and the status of protected areas: a landsat assessment. Remote Sens Environ 106: 460-466.

HUANG CQ ET AL. 2009. Assessment of Paraguay's forest cover change using landsat observations. Glob Planet Chang 67: 1-12.

IBGE. 2012. Manual técnico da vegetação brasileira. Rio de Janeiro: Instituto Brasileiro de Geografia e Estatística, 275 p.

KANIESKI MR, LONGHI SJ, NARVAES IS, SOARES PRC, LONGHI-SANTOS T AND CALLEGARO RM. 2012. Diversidade e padrões de distribuição espacial de espécies no estágio de regeneração natural em São Francisco de Paula, RS, Brasil. Floresta 42: 509-518.

KERSTEN RA, BORGO M AND GALVÃO F. 2015. Floresta Ombrófila Mista: aspectos fitogeográficos, ecológicos e métodos de estudo. In: Eisenlohr PV et al. (Eds), Fitossociologia no Brasil: métodos e estudos de casos. Viçosa: Editora UFV, p. 156-182.

KLAUBERG C, PALUDO GF, BORTOLUZZI RLC AND MANTOVANI A. 2010. Floristics and structure of a
Mixed Rain Forest remnant on the Catarinense Plateau Biotemas 23: 35-47.

KLEIN RM. 1960. O aspecto dinâmico do Pinheiro Brasileiro. Sellowia 12: 17-44.

KLEIN RM. 1978. Mapa fitogeográfico do Estado de Santa Catarina. In: Flora Ilustrada Catarinense. Itajaí: R. Reitz, p. 1.

KNAPE J AND VALPINE P. 2012. Are patterns of density dependence in the Global Population Dynamics Database driven by uncertainty about population abundance? Ecol Lett 15: 17-23.

LIEBSCH D, MARQUES MCM AND GOLDENBERG R. 2008. How long does the Atlantic Rain Forest take to recover after a disturbance? Changes in species composition and ecological features during secondary succession. Biol. conserv. 141: 1717-1725.

LIEBSCH D, MIKICH SB, POSSETTE RFS AND RIBAS OS. 2009. Floristic survey and dispersal syndromes in Araucaria Forest remnants of Parana state, Brazil. Hoehnea 36: 233-248.

LIEBSCH D AND MIKICH SB. 2009. Reproductive phenology of plant species of Mixed Ombrophilous Forest in Paraná, Brazil. Rev Bras Bot 32: 375-391.

LOPES CGR, FERRAZ EMN, CASTRO CC, LIMA EN, SANTOS JMFF, SANTOS DM AND ARAÚJO EL. 2012. Forest succession and distance from preserved patches in the Brazilian semiarid region. For Ecol Manage 271: 115123.

MAÇANEIRO JP, SEUBERT RC AND SCHORN LA. 2015. Phytosociology of a primary Subtropical Rain Forest in southern Brazil. Floresta 45: 555-566.

MAÇANEIRO JP, OLIVEIRA LZ, SEUBERT RC, EISENLOHR PV AND SCHORN LA. 2016a. More than environmental control at local scales: do spatial processes play an important role in $\mathrm{fl}$ oristic variation in subtropical forests? Acta Botanica Brasilica 30: 183-192.

MAÇANEIRO JP, SEUBERT RC, HEILMANN A AND SCHORN LA. 2016b. Regeneration of a Mixed Ombrophilous Forest on the Santa Catarina Plateau. Biotemas 29: 31-42.

MCGUINNES WG. 1934. The relation between frequency index and abundance as applied to plant populations in a semiarid region. Ecology 15: 263-282.

NARBONA E, ARISTA M AND ORTIZ PL. 2005. Explosive seed dispersal in two perennial Mediterranean Euphorbia species (Euphorbiaceae). Am J Bot 92: 510-516.

NASCIMENTO ART, LONGHI SJ AND BRENA DA. 2001. Structure and spatial distribution patterns of tree species in a Mixed Ombrophylous Forest sample in Nova Prata, RS. Ciênc Florest 11: 105-119.

NATHAN R AND MULLER-LANDAU HC. 2000. Spatial patterns of seed dispersal, their determinants and 
consequences for recruitment. Trends Ecol Evol 15: 278285.

NATHAN R, SAFRIEL UN AND NOY-MEIR I. 2001. Field validation and sensitivity analysis of a mechanistic model for tree seed dispersal by wind. Ecology 82: 374-388.

NATHAN R AND KATUL GG. 2005. Foliage shedding in deciduous forests lifts up long-distance seed dispersal by wind. Proc Natl Acad Sci USA 102: 8251-8256.

NATHAN R. 2006. Long-distance dispersal of plants. Science 313: 786-788.

NEGRINI M, AGUIAR MD, VIEIRA CT, SILVA AC AND HIGUCHI P. 2012. Dispersion, spatial distribution and vertical stratification of the tree community in a forest fragment in "Planalto Catarinense" region. Rev. Árvore 36: 919-929.

PADILHA DL, LOREGIAN AC AND BUDKE JC. 2015. Forest fragmentation does not matter to invasions by Hovenia dulcis. Biodivers Conserv 24: 2293-2304.

PAISE G AND VIEIRA EM. 2005. Fruit production and spatial distribution of animal-dispersed angiosperms in a Mixed Ombrophilous Forest in State of Rio Grande do Sul, Brazil. Rev Bras Bot 28: 615-625.

PANDOLFO C, BRAGA HJ, SILVA JÚNIOR VP, MASSIGNAN AM, PEREIRA ES, THOMÉ VMR AND VALCI FV. 2002. Atlas Climatológico do Estado de Santa Catarina. Florianópolis: Epagri. 1 CD-ROM.

PIJL LVD. 1982. Principles of dispersal in higher plants. New York: Springer-Verlag, $218 \mathrm{p}$.

PPG I. 2016. A community-derived classification for extant lycophytes and ferns. J Syst Evol 54: 563-603.

REIS MS ET AL. 2012. Distribuição da diversidade genética e conservação de espécies arbóreas em remanescentes florestais de Santa Catarina. In: Vibrans AC et al. (Ed), Inventário Florístico Florestal de Santa Catarina: Diversidade e Conservação dos remanescentes florestais. Blumenau: Edifurb, p. 143-169.

REITZ R AND KLEIN RM. 1966. Araucariáceas. In: Reitz R (Ed), Flora Ilustrada Catarinense. Itajaí: Herbário Barbosa Rodrigues, p. 1-62.

RIBEIRO MC, MARTENSEN AC, METZGER JP, TABARELLI M, SCARANO F AND FORTIN MJ. 2011. The Brazilian Atlantic forest: a shrinking biodiversity hotspot. In: Zachos FE and Habel JC (Eds), Biodiversity hotspots. Heidelberg: Springer, p. 405-434.

RICKLEFS RE. 2010. A Economia da Natureza. Rio de Janeiro: Guanabara Koogan, 572 p.

SCHUPP EW, MILLERON T AND RUSSO SE. 2002. Dissemination limitation and the origin and maintenance of species-rich tropical forests. In: Levey DJ et al. (Eds), Seed Dispersal and Frugivory: Ecology, Evolution and Conservation. New York: CABI Publishing, p. 19-33.

SEIDLER TG AND PLOTKIN JB. 2006. Seed dispersal and spatial pattern in tropical trees. PLoS Biol 4: 2132-2137.

SEVEGNANI L, VIBRANS AC AND GASPER AL. 2012. Considerações finais sobre a Floresta Ombrófila Mista em Santa Catarina. In: Vibrans AC et al. (Eds), Inventário Florístico Florestal de Santa Catarina: Floresta Ombrófila Mista. Blumenau: Edifurb, p. 275-278.

SILVA KE, MARTINS SV, SANTOS NT AND RIBEIRO CAAS. 2012. Padrões espaciais de espécies arbóreas tropicais. In: Martins SV (Eds), Ecologia de Florestas Tropicais do Brasil, p. 326-354.

STEHMANN JR, FORZZA RC, SALINO A, SOBRAL M, COSTA DP AND KAMINO LHY. 2009. Plantas da Floresta Atlântica. Rio de Janeiro: Instituto de Pesquisas Jardim Botânico do Rio de Janeiro, 516 p.

TABARELLI M, AGUIAR AV, RIBEIRO MC, METZGER JP AND PERES CA. 2010. Prospects for biodiversity conservation in the Atlantic Forest: Lessons from aging human-modified landscapes. Biol Conserv 10: 2328-2340.

TALORA DC AND MORELLATO PC. 2000. Phenology of coastal-plain forest tree from Southeastern Brazil. Rev Bras Bot 23: 13-26.

TRAVESET A, HELENO R AND NOGALES M. 2014. The ecology of seed dispersal. In: Gallagher RS (Eds), Seeds: the ecology of regeneration in plant communities. London: CABI Publishing, p. 62-93.

VANDER WALL SB, KUHN KM AND BECK MJ. 2005. Seed removal, seed predation, and secondary dispersal. Ecology 86: 801-806.

VIBRANS AC, MCROBERTS RE, LINGNER DV, NICOLETTI AL AND MOSER P. 2012. Extensão original e remanescentes da Floresta Ombrófila Mista em Santa Catarina. In: Vibrans AC et al. (Eds), Inventário Florístico Florestal de Santa Catarina: Floresta Ombrófila Mista. Blumenau: Edifurb, p. 25-31.

VIBRANS AC, MCROBERTS RE, MOSER P. AND NICOLETTI AL. 2013. Using satellite image-based maps and ground inventory data to estimate the area of the remaining Atlantic forest in the Brazilian state of Santa Catarina. Remote Sens Environ 130: 87-95.

WILSON RJ, THOMAS CD, FOX R, ROY DB AND KUNIN WE. 2004. Spatial patterns in species distributions reveal biodiversity change. Nature 432: 393-396.

ZAR JH. 2010. Biostatistical analysis. New Jersey: Pearson Prentice Hall, 944 p. 